\title{
Evaluation of antioxidant and anticancer effects of Piper betle L (Piperaceae) leaf extract on MCF-7 cells, and preparation of transdermal patches of the extract
}

\author{
Supavadee Boontha ${ }^{1 *}$, Jirapon Taowkaen ${ }^{1}$, Thanaporn Phakwan ${ }^{1}$, Teerapong \\ Worauaichai ${ }^{1}$, Piyarat Kamonnate ${ }^{1}$, Benjaporn Buranrat ${ }^{2}$, Tasana \\ Pitaksuteepong $^{3}$ \\ ${ }^{1}$ School of Pharmaceutical Sciences, University of Phayao, Phayao 56000, ${ }^{2}$ Faculty of Medicine, Mahasarakham University, \\ Maha Sarakham 44000, ${ }^{3}$ Department of Pharmaceutical Technology, Faculty of Pharmaceutical Sciences, Naresuan \\ University, Phitsanulok 65000, Thailand
}

*For correspondence: Email: supa0865@hotmail.com; Tel: +66-54-466666

Sent for review: 1 February 2019

Revised accepted: 23 May 2019

\begin{abstract}
Purpose: To determine the antioxidant and anticancer effects of Piper betle ( $P$. betle) leaf extract on human breast cancer MCF-7 cells, and to develop transdermal patches containing the extract.

Methods: The leaf extract of $P$. betle was prepared by maceration method, and its antioxidant activity was evaluated using 2, 2-diphenyl-1-picrylhydrazyl (DPPH) radical scavenging assay. Cytotoxicity and suppression of cell migration (indices of anticancer activity) were also assessed in MCF-7 cells by sulforhodamine B (SRB) and wound healing assays, respectively. Transdermal patches were developed using the casting method, and the resultant patches were evaluated with regard to their physical appearance and mechanical properties before and after a stability test.

Results: The extract exhibited antioxidant activity with half-maximal inhibitory concentration (IC $\left.C_{50}\right)$ of $30.0 \pm 0.1 \mu \mathrm{g} / \mathrm{mL}$. It also showed cytotoxicity with an $1 C_{50}$ of $114.3 \pm 14.9 \mu \mathrm{g} / \mathrm{mL}$, and significantly suppressed the migration of MCF-7 cells at a dose of $25 \mu \mathrm{g} / \mathrm{mL}$. Based on desirable characteristics, patch base formulations containing $4.2 \%$ pectin, $0.4 \%$ hydroxyl propyl methylcellulose (HPMC), $0.4 \%$ polyvinyl pyrrolidine K-90 (PVP-K90) and $3 \%$ propylene glycol (PG) were selected for incorporation into the extract.
\end{abstract}

Conclusion: Leaf extract of $P$. betle exhibits potential anti-breast cancer properties. A transdermal patch containing $0.03 \%$ of the extract can be successfully developed for treatment of breast cancer.

Keywords: Piper betle leaf, Transdermal patches, Breast cancer, Antioxidants

\begin{abstract}
This is an Open Access article that uses a fund-ing model which does not charge readers or their institutions for access and distributed under the terms of the Creative Commons Attribution License (http://creativecommons.org/licenses/by/4.0) and the Budapest Open Access Initiative (http://www.budapestopenaccessinitiative.org/read), which permit unrestricted use, distribution, and reproduction in any medium, provided the original work is properly credited.

Tropical Journal of Pharmaceutical Research is indexed by Science Citation Index (SciSearch), Scopus, International Pharmaceutical Abstract, Chemical Abstracts, Embase, Index Copernicus, EBSCO, African Index Medicus, JournalSeek, Journal Citation Reports/Science Edition, Directory of Open Access Journals (DOAJ), African Journal Online, Bioline International, Open-J-Gate and Pharmacy Abstracts
\end{abstract}

\section{INTRODUCTION}

Breast cancer is one of the deadliest diseases, and the most common cancer in women worldwide. Currently, treatment failures in breast cancer are associated with drug resistance and drug toxicity [1]. Thus, there is need for development of newer and less toxic chemotherapeutic agents. Recently, many researchers have focused attention on medicinal 
plant extracts rich in flavonoids and phenolic compounds as potential sources of alternative chemotherapeutic agents. This is due to reports from many studies showing that these compounds exert anticancer effects [2,3]. Moreover, positive correlations have been established between the antioxidant activities of plant extracts and their proliferative inhibition effects [4].

Piper betle $\mathrm{L}$ (Piperaceae) are generally named as betel leaf. It is one of many medicinal plants that have become popular in cancer studies [5]. Studies have shown that leaf extract of $P$. betle possess phenolic compounds such as hydroxychavicol, chavibetol and eugenol $[5,6]$. In addition, it has been noted that leaf extract of $P$. betle exhibits antioxidant activity, as revealed through DPPH, hydroxyl, nitric oxide and superoxide anion radical scavenging activities, as well as ferric reducing antioxidant power (FRAP) assay. Moreover, the anti-proliferative effect of $P$. betle leaf extract has been documented against B lymphocyte cell line (Raji cells) [7], KERATIN-forming tumor cell line (KB cells) [8], and MCF-7 cells [9]. These findings indicate the potential of the extract for use in the breast cancer treatment. However, not much is known about the effect of the leaf extract of $P$. betle on MCF-7 cell migration. Cancer metastasis is a crucial step in the prognosis of cancer patients [10]. The wound healing assay is usually used to determine migration of cancer cells. The inhibitory potential of $P$. betle leaf extract on the migration of MCF-7 cells can be demonstrated though its suppression of relative closure of scratch wound in the wound healing assay. If the extract suppresses healing of the scratch would, it may be reasonably concluded that it reduces cancer cell metastasis, implying that its application may result in good prognosis of cancer patients. Then, the extract could be considered as exerting good chemo-preventive effect.

Transdermal patches are dosage forms formulated for effective delivery of active principles/compounds at controlled rates, and within predictable times [11,12]. Transdermal administration is one of the promising alternative routes for delivery of anticancer drugs due to its safety, ease of administration, reduced frequency of dosing, by passing of hepatic first-pass effect, and reduce incidence of adverse side effects, when compared with the oral route [11].

This present study was examined the determination of the antioxidant and anticancer activities of leaf extract of $P$. betle on human breast cancer (MCF-7) cells, and development of transdermal patches of the extract.

\section{EXPERIMENTAL}

\section{Preparation of $\boldsymbol{P}$. betle leaf extract}

The $P$. betle leaves were collected from the botanical garden of School of Pharmaceutical Sciences, University of Phayao, from October to December, 2018. The plant sample was identified by Dr. Prachaya Srisanga, Herbarium Curator at The Botanical Garden Organization, Queen Sirikit Botanic Garden (QBG). A voucher specimen was deposited at the QBG Herbarium, Chiang Mai (QBG voucher number 110895). The fresh leaves were washed, chopped into small pieces and air-dried. They were further dried at $50{ }^{\circ} \mathrm{C}$ using a hot-air oven for $48 \mathrm{~h}$. The dried leaves were ground into powder, and were extracted with $95 \%$ ethanol for $72 \mathrm{~h}$. Following filtration, the extract was concentrated using a rotary evaporator (Heidolph, Germany) at controlled temperature of $50^{\circ} \mathrm{C}$. The percentage yield of the extract was determined using Eq 1.

Yield $(\%)=($ WCE $)($ WLP $) 100$

where WCE is dried weight of the crude extract, and WLP is dried weight of the $P$. betle leaf powder.

\section{Evaluation of total phenolic and flavonoid contents, and antioxidant activity}

\section{Phenolic content}

In the evaluation of total phenolic content (TPC) of the extract, $40 \mu \mathrm{L}$ of the extract $(200 \mu \mathrm{g} / \mathrm{mL})$ was mixed with $80 \mu \mathrm{L}$ of Folin-Ciocalteu reagent for $5 \mathrm{~min}$. Thereafter, $7 \%$ sodium carbonate $\left(\mathrm{Na}_{2} \mathrm{Co}_{3}\right)$ was added to the mixture, and the reaction mixture was incubated for $30 \mathrm{~min}$. The solution absorbance was determined at $750 \mathrm{~nm}$ using a microplate reader (Synergy H1, Biotek Instruments, Friedrichshall, Germany). The TPC was determined using a gallic acid standard curve prepared using gallic acid with a serial concentrations of $20-100 \mu \mathrm{g} / \mathrm{mL}$. The TPC was presented as gallic acid equivalent (GAE) per gram of crude extract.

\section{Flavonoid content}

In the evaluation of total flavonoid content (TFC) of the extract, $100 \mu \mathrm{L}$ of $2 \%$ aluminum chloride $\left(\mathrm{AlCl}_{3}\right)$ solution was added to the sample solution $(100 \mu \mathrm{g} / \mathrm{mL}, 100 \mu \mathrm{L})$. After incubation for $10 \mathrm{~min}$, the absorbance intensity was measured at 415 $\mathrm{nm}$. The TFC was calculated from the standard 
curve of rutin $(20-100 \mu \mathrm{g} / \mathrm{mL})$ and presented as rutin equivalent ( $\mathrm{RE}$ ) per $\mathrm{g}$ of the crude extract.

\section{Antioxidant activity}

In the evaluation of antioxidant activity, the extract solution was prepared by dissolving the extract in $95 \%$ ethanol to obtain concentrations of $0.05-2.0 \mathrm{mg} / \mathrm{mL}$. Then, $100 \mu \mathrm{L}$ of each extract solution was separately mixed with 100 $\mu \mathrm{L}$ of $5.0 \mathrm{mM}$ DPPH in a 96-well plate. Following incubation at room temperature for $20 \mathrm{~min}$, absorbance of the control (without the test sample, $\left.A_{\text {blank }}\right)$ and that of the sample $\left(A_{\text {sample }}\right)$ were determined at $540 \mathrm{~nm}$. Gallic acid served as a positive control. The DPPH radical scavenging ability (D) was determined using Eq 2.

$D \%=\left\{\left(A_{\text {blank }}-A_{\text {sample }}\right) / A_{\text {blank }}\right\} 100$

\section{Evaluation of effects of $P$. betle extract on cytotoxicity and cell migration}

\section{Cell culture and cytotoxicity assay}

In the determination of cytotoxic activity of $P$. betle extract, the human breast cancer cell, MCF-7, (ATCC \#HTB-22, Manassas, USA) was cultured in Dulbecco's Modified Eagle Medium (DMEM) supplementing of $10 \%$ fetal bovine serum (FBS), $100 \mu \mathrm{g} / \mathrm{mL}$ streptomycin and 100 $\mathrm{U} / \mathrm{mL}$ penicillin. The SRB method was used to determine the cytotoxic activity as previously described $[12,13]$. Cells were plated, exposed to the medium containing $P$. betle extract $(0-250$ $\mu \mathrm{g} / \mathrm{mL}$ ) for $48 \mathrm{~h}$ and then cells were stained with $0.4 \%$ SRB for 30 min at room temperature. After incubation time, cells were discarded SRB dye, washed several times to remove excess SRB dye, and solubilized in Tris base buffer $(10 \mathrm{mM}$, $\mathrm{pH}$ 7.4). The absorbance were measured at 540 nm using a microplate reader (Opsys MRTM, Dynex Technologies, USA).

\section{Suppression of cell migration}

In the determination of anti-migratory effect of the extract, the cells were plated onto 24-wells culture plate for $24 \mathrm{~h}$ at $37^{\circ} \mathrm{C}$. Then, cell was created a straight wound by scratching the cell with a sterile pipette tip, and the cells were separately incubated with various doses of the extract $(0-100 \mu \mathrm{g} / \mathrm{mL})$ for $48 \mathrm{~h}$. Thereafter, the area of the uncovered region of the wound was measured using an inverted microscope (TS100, Nikon, Japan) at a magnification of x10 $[14,15]$. The percentage of relative closure of the scratch was calculated from the area data.

\section{Formulation of transdermal patch base}

The transdermal patch base was formulated using a film casting method. Three types of polymers i.e. pectin, HPMC and PVP-K 90 were used as film-formers, while propylene glycol (PG) or PEG-400 act as plasticizer, and paraben served as a preservative. Based on the best physical appearance of the preliminary trial batch (data not shown), the three types of polymers were combined at various ratios to generate a fixed polymer amount at $5 \%(\mathrm{w} / \mathrm{w})$ in each patch formulation. The amount of plasticizer used was varied from 1 to $5 \%(\mathrm{w} / \mathrm{w})$. The compositions and formulation code of the preliminary trial batches are shown in Table 1.

The polymers were completely dissolved in distilled water. Then, the plasticizer and preservative were added under continuous stirring for $60 \mathrm{~min}$. The polymer solutions were left at room temperature overnight to remove air bubbles. Then, $50 \mathrm{~g}$ of the polymer solution was poured on a petri dish and dried at $40{ }^{\circ} \mathrm{C}$ using a hot-air oven (Memmert, Schwabach, Germany). The dried patches were removed from the petri dish, wrapped in aluminum foil, and preserved in a desiccator prior to use.

\section{Characterization of transdermal patch bases}

\section{Physical appearance}

The patches were visually observed for color, homogeneity and flexibility.

\section{Mechanical properties}

The tensile strength of each patch was evaluated by a texture analyzer (TA.XT. plus, Stable Micro System, Surrey, UK). The patch was cut into shape of rectangular of $7 \mathrm{~cm}$ in length, and $1 \mathrm{~cm}$ in width. The patch was fixed between two cell grips of the instrument, with one grip fixed, and the other movable. A force was gradually applied to pull the patch until it was torn at the center. The tensile strength was calculated from Eq 3.

Tensile strength $=($ force at breaking point $)($ area of the sample)

Elongation $(\mathrm{E})$ was determined by comparing the lengths of each patch strip after the break point $(F L)$ was reached, to the initial length of each patch strip before the break point (IL) was reached, as shown in Eq 4.

$E(\%)=\{(F L-I L)\rangle(I L)\} 100$ 


\section{Preparation and characterization of patches containing $P$. betle leaf extract}

Patch base formulations with good physical appearance and mechanical properties were selected for incorporation of the extract. The extract was dissolved in the blended polymer solution before mixing with other ingredients. The patches containing the extract were evaluated for their physical appearance and mechanical properties as described above. Weight variation, uniformity of thickness, and water uptake of the $P$. betle leaf extract containing patches were determined as indicated.

\section{Weight variation}

A set of three patches from each patch base, and patches containing the extract formulation with a diameter of $1 \mathrm{~cm}^{2}$ were weighed on a digital balance (New Classic MF, ML802, Mettler Toledo, Switzerland) and the mean values were calculated.

\section{Thickness uniformity}

The thicknesses of the patches were measured using a vernier caliper (Macoh, Thailand) at five different places, and the mean values were determined.

\section{Water uptake}

Patches of each formulation were cut into $1 \times 1$ $\mathrm{cm}$ squares. The squares were accurately weighed and soaked in distilled water $(2 \mathrm{~mL})$ at $37^{\circ} \mathrm{C}$ for $5 \mathrm{~min}$. The patches were removed from the water and hung in the air to remove excess free water on their surfaces. They were then weighed again, and water uptake (W) was calculated as shown in Eq 5.

$W(\%)=\{($ FPW - IPW $)\rangle(I P W)\} 100$

where FPW is final patch weight, and IPW is initial patch weight.

\section{Stability studies}

Stability studies on the prepared patches were carried out using heat/cool cycling test. In heat/cool cycling test, the patches were packed into aluminum foil and kept at $4{ }^{\circ} \mathrm{C}$ for $24 \mathrm{~h}$, followed by kept at $60{ }^{\circ} \mathrm{C}$ for $24 \mathrm{~h}$. This process was repeated in five cycles. The physical appearance, tensile strength, elongation, weight variation, thickness uniformity and water uptake of the prepared patch formulations were evaluated when first prepared, and after heat/cool cycling test.

\section{Statistical analysis}

The data values are shown in term of means \pm standard deviation (SD). Statistical data analysis was done by a one-way analysis of variance (ANOVA) (Sigma Stat software version 3.5). Set value of $p<0.05$ was considered statistical significance.

\section{RESULTS}

Physical appearance, TPC, TFC and antioxidant activity of extract

The leaf extract of $P$. betle was obtained as a dark-green paste at a percentage yield of approximately $1.4 \%(\mathrm{w} / \mathrm{w})$. The crude extract had TPC of $626.4 \pm 60.5 \mathrm{mg} \mathrm{GAE} / \mathrm{g}$, and TFC of $138.5 \pm 20.2 \mathrm{mg} \mathrm{RE} / \mathrm{g}$. It exhibited antioxidant activity with $\mathrm{IC}_{50}$ of $30.0 \pm 0.1 \mu \mathrm{g} / \mathrm{mL}$, relative to that of gallic acid $\left(\mathrm{IC}_{50}\right.$ of $\left.8.2 \pm 0.5 \mu \mathrm{g} / \mathrm{mL}\right)$.

\section{Cytotoxic effect of $\boldsymbol{P}$. betle extract on breast cancer cells}

The extract exerted cytotoxic activity on MCF-7 cells. The MCF-7 cell viability was decreased when increasing dose of the extract and it decreased the MCF-7 cell viability with an $\mathrm{IC}_{50}$ of $114.3 \pm 14.9 \mu \mathrm{g} / \mathrm{mL}$ (Figure 1). In addition, it showed a significant impact at a concentration of $50 \mu \mathrm{g} / \mathrm{mL}$.

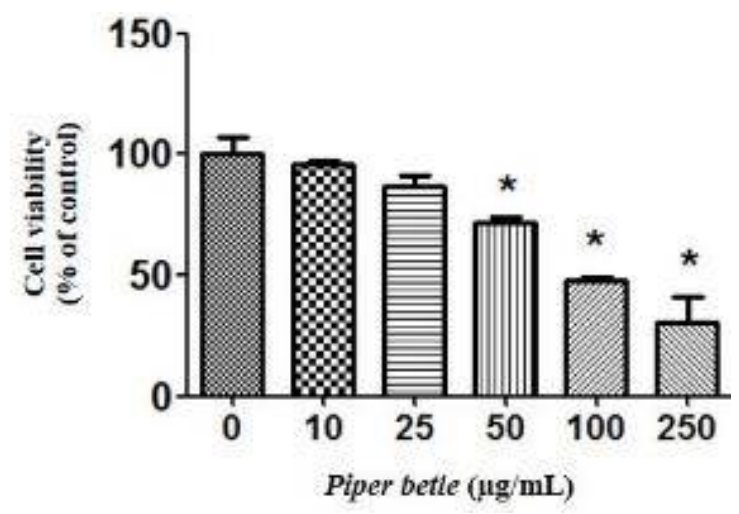

Figure 1: Cytotoxic activity of leaf extract of $P$. betle on MCF-7 cells, relative to control after $24 \mathrm{~h}$

\section{Anti-migratory effect of extract of $P$. betle on breast cancer cells}

The results showed that the $P$. betle extract suppressed migration of the cancer cells in a concentration-dependent manner, with a significant effect at a concentration of $25 \mu \mathrm{g} / \mathrm{mL}$ (Figure 2 a). At this concentration, the extract suppressed the migration of breast cancer cells by approximately $30 \%$, relative to the control group (Figure 2 b). 


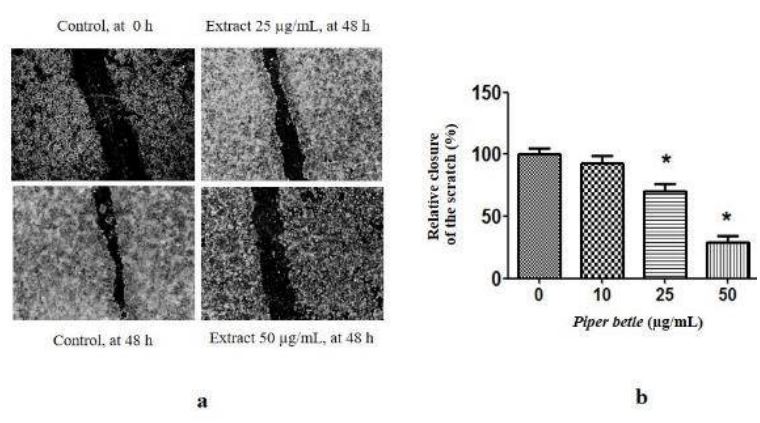

Figure 2: Pictures of migration of MCF-7 cancer cells incubated with the leaf extract of $P$. betle, and control for $48 \mathrm{~h} \mathrm{(a)}$. Effect of the extract on percentage relative closure of scratch wound after treatment for $48 \mathrm{~h}$, relative to control (b)

\section{Characteristics of patch base formulations}

Ten patch base formulations were given product codes F-1 to F-10 (Table 1). All formulations were yellowish, homogeneous, flexible and smooth films (data not shown). There were no problems removing the prepared patch base formulations from the petri dishes after ovendrying. The tensile strength and percentage elongation indicated the strength and elasticity of the patches, respectively [16]. The mechanical properties of the patch bases are shown in Figure 3. All patches of the prepared formulations exhibited percentage elongation at break values in the range of $29.88-72.88 \%$, and they showed tensile strength values in the range of $0.35-3.49 \mathrm{~N} / \mathrm{mm}^{2}$. In general, preferable patches for transdermal application should be flexible enough to follow the movements of the skin without breaking and the films should be strong enough to prevent abrasion of the films during contact with clothing [17]. Patch base formulation F-3 was selected for use in the preparation of transdermal patch containing the extract because it exhibited a high percentage elongation at break of $76.13 \pm 12.68$ $\%$ with a tensile strength of $1.19 \pm 0.31 \mathrm{~N} / \mathrm{mm}^{2}$
(Figure 3). The extract was added to the patch formulation at the level of $0.03 \%(w / w)$.

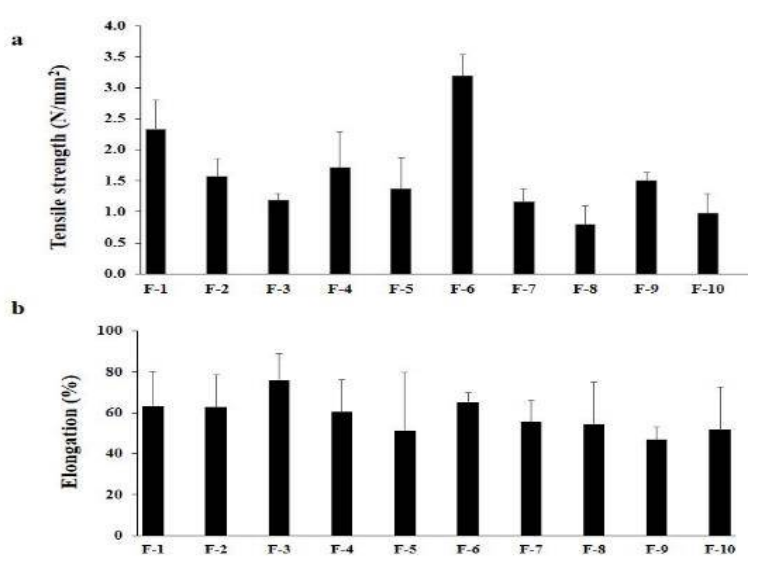

Figure 3: Tensile strength (a) and elongation (b) of patches

\section{Characteristics of patch base and patch containing leaf extract of $P$. betle}

The patch base was light yellow in color, while the patch containing the extract appeared dark green in color due to the color of the extract (Figure 4). The mechanical properties, weight, thickness and water uptake of the patches are shown in Table 2. Compared with the transdermal patch base, the tensile strength of patch containing the extract was increased, whereas the elongation was decreased.

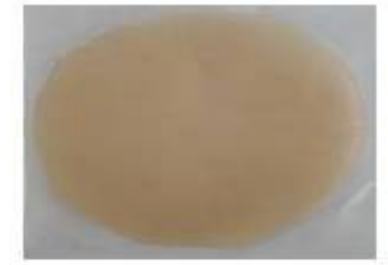

a

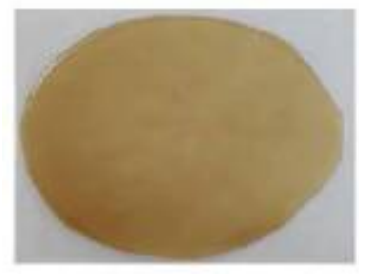

b
Figure 4: Physical appearance of (a) patch base (F-3) and (b) patch containing the extract

Table 1: Composition and formulation code given of patch base prepared

\begin{tabular}{|c|c|c|c|c|c|c|c|c|c|c|c|}
\hline \multirow[t]{2}{*}{ Composition } & \multirow[t]{2}{*}{ Function } & \multicolumn{10}{|c|}{ Amount (mg) } \\
\hline & & $\mathrm{F}-1$ & F-2 & F-3 & F-4 & F-5 & F-6 & F-7 & F-8 & F-9 & F-10 \\
\hline Pectin & Film-former & 4.2 & 4.2 & 4.2 & 4.2 & 1.67 & 0.4 & 3.0 & 3.6 & 4.2 & 1.0 \\
\hline HPMC & Film-former & 0.4 & 0.4 & 0.4 & 0.4 & 1.67 & 0.4 & 1.0 & 0.7 & 0.4 & 1.0 \\
\hline PVP K-90 & Film-former & 0.4 & 0.4 & 0.4 & 0.4 & 1.67 & 0.4 & 1.0 & 0.7 & 0.4 & 3.0 \\
\hline$P G$ & Plasticizer & 1.0 & 2.0 & 3.0 & 4.0 & 5.0 & - & - & - & - & - \\
\hline PEG-400 & Plasticizer & - & - & - & - & - & 1.0 & 2.0 & 3.0 & 4.0 & 5.0 \\
\hline Paraben & Preservative & 1.0 & 1.0 & 1.0 & 1.0 & 1.0 & 1.0 & 1.0 & 1.0 & 1.0 & 1.0 \\
\hline Water & Solvent & 93 & 92 & 91 & 90 & 89 & 93 & 92 & 91 & 90 & 89 \\
\hline Total weight & - & 100 & 100 & 100 & 100 & 100 & 100 & 100 & 100 & 100 & 100 \\
\hline
\end{tabular}


Table 2: Physical appearance and mechanical properties of patch before and after stability test

\begin{tabular}{|c|c|c|c|c|c|}
\hline Formulation & $\begin{array}{l}\text { Tensile strength } \\
\left(\mathrm{N} / \mathrm{mm}^{2}, \pm \mathrm{SD}\right)\end{array}$ & $\begin{array}{c}\text { Elongation (\%) } \\
\pm \text { SD }\end{array}$ & $\begin{array}{c}\text { Weight } \\
(\mathrm{mg} \pm \mathrm{SD})\end{array}$ & $\begin{array}{l}\text { Thickness } \\
\text { (mm, } \pm \text { SD) }\end{array}$ & $\begin{array}{c}\text { Water uptake (\%) } \\
\pm \text { SD }\end{array}$ \\
\hline \multicolumn{6}{|l|}{ Patch base } \\
\hline Before test & $1.19 \pm 0.31$ & $76.13 \pm 12.68$ & $81.7 \pm 0.6$ & $0.73 \pm 0.10$ & $46.76 \pm 5.84$ \\
\hline After test & $2.33 \pm 0.58^{\#}$ & $56.73 \pm 15.80^{\#}$ & $58.0 \pm 0.9^{\#}$ & $0.60 \pm 0.07$ & $203.98 \pm 14.70^{\#}$ \\
\hline \multicolumn{6}{|c|}{ P. betle patch ${ }^{*}$} \\
\hline Before test & $1.45 \pm 0.11$ & $65.18 \pm 2.92$ & $65.4 \pm 2.8$ & $0.67 \pm 0.10$ & $98.17 \pm 26.66$ \\
\hline After test & $1.59 \pm 0.07$ & $47.02 \pm 2.88^{\#}$ & $59.8 \pm 0.1$ & $0.61 \pm 0.01$ & $206.40 \pm 7.63^{\#}$ \\
\hline
\end{tabular}

\section{Stability}

The results of stability test showed that the weight, thickness and percentage elongation of the patch base were decreased, whereas percentage water uptake and the tensile strength of the patch were increased. Similar results were obtained with the patch containing the extract (Table 2).

\section{DISCUSSION}

Nowadays, there are attempts to discover potent anticancer agents from herbal medicine, especially anti-cancer agents with low toxicity. A few studies have reported that medicinal plants with high antioxidant activities suppress the proliferation of cancer cells [2,3]. The present study was assessed the antioxidant and anticancer effects of $P$. betle leaf extract on the human breast cancer cells, MCF-7. The results indicated that the $P$. betle leaf extract of had high antioxidant activity, most likely due to the presence of phenolic and flavonoid compounds in the extract. In addition, it has been reported that phenolic compounds and flavonoids have both chemotherapeutic and chemo-preventive effects [2-4]. The results revealed that the leaf extract of $P$. betle exerted dose-dependent anticancer activity against breast cancer cells. These findings are in agreement with previous reports [9]. Moreover, the extract inhibited metastasis of MCF-7 cells. Thus, the leaf extract of $P$. betle inhibits cancer metastasis and exerts chemo-preventive effects.

Reactive oxygen species (ROS) have been related with cancer pathogenesis. The anticancer activity of the $P$. betle extract may be due to its high antioxidant activity. In a study, it was revealed that hydroxychavicol, a crucial phenolic in $P$. betle leaf extract, was metabolized to an electrophile which conjugated with reduced glutathione; this increases the ROS sensitivity of cancer cells, resulting in enhanced apoptosis [18]. The cytotoxic and anti-migratory effects of the extract on MCF-7 cells suggest that local treatment i.e. application of the extract on the breast skin might produce effective outcomes. Consequently, the $P$. betle leaf extract was converted into transdermal patches, based on the finding that it was preserved in the patch formulation, and it exerted prolonged anticancer effect after the patch was applied on the skin.

To develop transdermal patch formulations, pectin was selected as a major component of the polymer blend due its good gelling property, high stability, biocompatibility and affordability $[19,20]$. The tensile strength of the prepared patch base decreased with increasing plasticizer concentration, due to the fact that plasticizers reduced the intermolecular forces between the chains of adjacent macromolecules [21]. Stability tests revealed that the prepared patch was stable throughout the study period. However, it is important to investigate the long-term stability and release profiles of the prepared patches in further studies.

\section{CONCLUSION}

The results obtained in present study indicate that the leaf extract of $P$. betle exerts antioxidant activity, also inhibits the viability and migration of MCF-7 cells. Thus, the extract has promising potential for development into an anticancer agent for breast cancer. This study is the first to develop $P$. betle patch against breast cancer. A transdermal patch containing the extract was successfully developed. The developed patch has potential uses for local treatment of breast cancer.

\section{DECLARATIONS}

\section{Acknowledgement}

This study was financially supported by School of Pharmaceutical Sciences, University of Phayao, Thailand and Thailand Research Fund (Grant no. MRG6080071). The authors would also like to express their appreciation to $\mathrm{Mr}$ Kamchai Saepang for technical assistance with texture analysis. 


\section{Conflict of interest}

No conflict of interest is associated with this study.

\section{Contribution of authors}

We declare that this work was done by the authors named in this article, and all liabilities pertaining to claims relating to the content of this article will be borne by them. Supavadee Boontha designed the study and the experiments, and prepared the manuscript. Tasana Pitaksuteepong assisted in experimental work and appraised the manuscript. Benjaporn Buranrat was responsible for MCF-7 cell study. Jirapon Taowkaen, Thanaporn Phakwan, Teerapong Worauaichai and Piyarat Kamonnate prepared the extract and participated in formulation of the patch.

\section{Open Access}

This is an Open Access article that uses a funding model which does not charge readers or their institutions for access and distributed under the terms of the Creative Commons Attribution License (http://creativecommons.org/licenses/by/ 4.0) and the Budapest Open Access Initiative (http://www.budapestopenaccessinitiative.org/rea d), which permit unrestricted use, distribution, and reproduction in any medium, provided the original work is properly credited.

\section{REFERENCES}

1. Valero $V$, Hortobagyi GN. Are anthracycline-taxane regimens the new standard of care in the treatment of metastatic breast cancer? J Clin Oncol 2003; 21: 959962.

2. Seeram NP, Zhang $Y$, Nair MG. Inhibition of proliferation of human cancer cells and cyclooxygenase enzymes by anthocyanidins and catechins. Nutr Cancer 2003; 46 : 101-106.

3. Thangapazham RL, Singh AK, Sharma A, Warren J, Gaddipati JP, Maheshwari RK. Green tea polyphenols and its constituent epigallocatechin gallate inhibits proliferation of human breast cancer cells in vitro and in vivo. Cancer Lett 2007; 245: 232-241.

4. Li WY, Chan SW, Guo DJ, Yu PHF. Correlation between antioxidative power and anticancer activity in herbs from traditional Chinese medicine formulae with anticancer therapeutic effect. Pharm Biol 2007; 45: 541-546.

5. Paranjpe R, Gundala SR, Lakshminarayana N, Sagwal A, Asif G, Pandey A, Aneja R. Piper betel leaf extract: anticancer benefits and bio-guided fractionation to identify active principles for prostate cancer management. Carcinogenesis 2013; 34: 1558-1566.
6. Gundala SR, Aneja R. Piper betel leaf: a reservoir of potential xenohormetic nutraceuticals with cancerfighting properties. Cancer Prev Res (Phila) 2014; 7: 477-486.

7. Murakami A, Ali AM, Mat-Salleh K, Koshimizu K, Ohigashi $H$. Screening for the In Vitro Anti-tumorpromoting Activities of Edible Plants from Malaysia. Biosci Biotechnol Biochem 2000; 64: 9-16.

8. Fathilah RA, Sujata $R$, Norhanom AW, Adenan MI. Antiproliferative activity of aqueous extract of Piper betle $L$. and Psidium guajava $L$. on $K B$ and HeLa cell lines. Planta Med 2010; 4: 987-990.

9. Abrahim NN, Kanthimathi MS, Abdul-Aziz A. Piper betle shows antioxidant activities, inhibits MCF-7 cell proliferation and increases activities of catalase and superoxide dismutase. BMC Complement Altern Med 2012; 12: 220-220.

10. Amith SR, Wilkinson JM, Fliegel L. Assessing $\mathrm{Na}+/ \mathrm{H}$ exchange and cell effector functionality in metastatic breast cancer. Biochim Open 2016;2:16-23.

11. Prausnitz MR, Langer R. Transdermal drug delivery. Nat Biotechnol 2008; 26: 1261-1268.

12. Agrawal SS, Pruthi JK. Development and evaluation of matrix type transdermal patch of ethinylestradiol and medroxyprogesterone acetate for anti-implantation activity in female Wistar rats. Contraception 2011; 84: 533-538.

13. Buranrat B, Suwannaloet $W$, Naowaboot J. Simvastatin potentiates doxorubicin activity against MCF-7 breast cancer cells. Oncol Lett 2017; 14: 6243-6250.

14. Buranrat B, Mairuae N, Kanchanarach W. Cytotoxic and antimigratory effects of Cratoxy formosum extract against HepG2 liver cancer cells. Biomed Rep 2017; 6: 441-448.

15. Buranrat $B$, Senggunprai L, Prawan A, Kukongviriyapan V. Simvastatin and atorvastatin as inhibitors of proliferation and inducers of apoptosis in human cholangiocarcinoma cells. Life Sci 2016; 153: 41-49.

16. Jantrawut $P$, Chaiwarit $T$, Jantanasakulwong $K$, Brachais $H C$, Chambin O. Effect of plasticizer type on tensile property and in vitro indomethacin release of thin films based on low-methoxyl pectin. Polymers 2017; 9, 289.

17. Bourtoom T. Plasticizer effect on the properties of biodegradable blend film from rice starch-chitosan. Songklanakarin J Sci Technol 2008; 30: 149-165.

18. Nakagawa $Y$, Suzuki $T$, Nakajima $K$, Ishii $H$, Ogata $A$. Biotransformation and cytotoxic effects of hydroxychavicol, an intermediate of safrole metabolism, in isolated rat hepatocytes. Chem Biol Interact 2009; 180: 89-97.

19. Thakur BR, Singh RK, Handa AK. Chemistry and uses of pectin-a review. Crit Rev Food Sci Nutr 1997; 37: 4773.

20. Espitia PJP, Du W-X, Avena-Bustillos RdJ, Soares NdFF, McHugh TH. Edible films from pectin: physicalmechanical and antimicrobial properties - A review. Food Hydrocolloids 2014; 35: 287-296.

Trop J Pharm Res, June 2019; 18(6): 1271 
21. Rajan R, Sheba Rani ND, Kajal G, Sanjoy Kumar D, Jasmina $K$, Arunabha $N$. Studies on the effect of plasticizer on in vitro release and ex vivo permeation from eudragit $E 100$ based chlorpheniramine maleate matrix type transdermal delivery system. J Excip Food Chem 2010; 1(2): 3-12. 